University of Nebraska - Lincoln

DigitalCommons@University of Nebraska - Lincoln

USDA National Wildlife Research Center - Staff Publications
U.S. Department of Agriculture: Animal and Plant Health Inspection Service

April 2000

\title{
Changes in coyote activity patterns due to reduced exposure to human persecution
}

Ann M. Kitchen

Utah State University, Logan, UT

Eric M. Gese

Utah State University, eric.gese@usu.edu

Edward R. Schauster

Utah State University, Logan, UT

Follow this and additional works at: https://digitalcommons.unl.edu/icwdm_usdanwrc

Part of the Environmental Sciences Commons

Kitchen, Ann M.; Gese, Eric M.; and Schauster, Edward R., "Changes in coyote activity patterns due to reduced exposure to human persecution" (2000). USDA National Wildlife Research Center - Staff Publications. 658.

https://digitalcommons.unl.edu/icwdm_usdanwrc/658

This Article is brought to you for free and open access by the U.S. Department of Agriculture: Animal and Plant Health Inspection Service at DigitalCommons@University of Nebraska - Lincoln. It has been accepted for inclusion in USDA National Wildlife Research Center - Staff Publications by an authorized administrator of DigitalCommons@University of Nebraska - Lincoln. 


\title{
Changes in coyote activity patterns due to reduced exposure to human persecution
}

\author{
Ann M. Kitchen, Eric M. Gese, and Edward R. Schauster
}

\begin{abstract}
Activity patterns in animals are influenced by a number of factors, including the animal's physiological adaptations, prey availability and distribution, and disturbances caused by predators and humans. We compared coyote (Canis latrans) activity patterns estimated using radio-tracking locations between 1983 and 1988 with those documented between 1996 and 1997 on the Pinon Canyon Maneuver Site, in southeastern Colorado. We tested the hypothesis that changes in the type of disturbance experienced by coyotes would result in changes in their activity patterns. Disturbance experienced by the coyote population studied during 1983-1988, included $>50$ years of intense exploitation (shooting and trapping by ranchers) and intensive removal efforts using aerial gunning. In contrast, coyotes tracked during 1996-1997 experienced some periodic disturbance from army maneuvers occurring in the area, but were not exposed to any direct form of persecution (e.g., shooting). From August 1983 to July 1988, 49 coyotes (26 males and 23 females) were tracked for $>2400 \mathrm{~h}$ using radiotelemetry. From April 1996 to August 1997, 22 coyotes (12 males and 10 females) were tracked for $>950 \mathrm{~h}$. The average rate of diurnal movement of the coyotes in the 1996-1997 field study $(\bar{x}=0.97 \mathrm{~km} / \mathrm{h})$ was significantly higher than that of the coyotes in the $1983-1988$ field study $(\bar{x}=0.68 \mathrm{~km} / \mathrm{h})$. This occurred despite no significant increase in the overall $(24 \mathrm{~h})$ rate of movement between the two field studies. Estimates of prey use by the coyotes in both field studies were obtained, to test an alternate hypothesis that prey switching might explain the changes in coyote movement patterns. However, there was no significant difference between the frequency of occurrence of diurnally versus nocturnally active mammalian prey species in the diets of coyotes in any season or overall between the 1983-1988 and 1996-1997 field studies. This study demonstrated that coyote activity patterns can be influenced by the type of disturbance experienced by the animal. A coyote population that had historically been exposed to human persecution shifted to higher levels of diurnal activity when exploitation ceased.
\end{abstract}

Résumé : L'activité des animaux est influencée par plusieurs facteurs, notamment les adaptations physiologiques de l'animal, la disponibilité et la répartition des proies et les perturbations créées par les prédateurs et les humains. Nous avons comparé les patterns d'activité des Coyotes (Canis latrans) basés sur des donnée de repérage- radio de 1983 à 1988 à ceux obtenus en 1996-1997 à Pinon Canyon Maneuver Site, dans le sud-est du Colorado. Nous avons posé en hypothèse que les changements dans le type de perturbation subie par un coyote entraînent des changements dans ses patterns d'activité. Parmi les perturbations subies par la population de coyotes au cours d'une étude en nature de 1983 à 1988, il faut compter plus de 50 ans d'exploitation assidue (chasse et piégeage par les propriétaires de ranches) et les tentatives intenses d'éradication par chasse aérienne aux armes à feu. Les coyotes suivis en 1996-1997 ont subi des perturbations périodiques reliées aux manoeuvres militaires dans la région, mais n'ont été exposés à aucune forme de persécution directe (i.e., la chasse aux armes à feu). D'août 1983 à juillet 1988, 49 coyotes (26 mâles, 23 femelles) ont été suivis pendant plus de $2400 \mathrm{~h}$ par radio-télémétrie. D'avril 1996 à août 1997, 22 coyotes (12 mâles, 10 femelles) ont été suivis pendant plus de $950 \mathrm{~h}$. Le taux moyen de déplacement pendant le jour chez les coyotes de 1996-1997 $(\bar{x}=0,97 \mathrm{~km} / \mathrm{h})$ était significativement plus élevé que celui mesuré chez les coyotes au cours de l'étude de 1983-1988 $(\bar{x}=0,68 \mathrm{~km} / \mathrm{h}$ ), et pourtant il ne s'est pas produit de changement significatif du taux global de déplacement (24 h) entre les deux études. Nous avons procédé à des estimations de l'utilisation des proies pendant les deux études dans le but d'éprouver une autre hypothèse selon laquelle le changement de proie peut expliquer les modifications enregistrées dans les déplacements. Cependant, nous n'avons pas trouvé de différence significative dans la fréquence des mammifères nocturnes et des mammifères diurnes dans le régime alimentaire des coyotes, ni de manière saisonnière, ni globalement, entre 1983-1988 et 1996-1997. Cette étude démontre que les patterns d'activité des coyotes peuvent être influencés par les types de perturbations subies par l'animal. Une population de coyotes exposée à la persécution humaine pendant longtemps a adopté un mode de vie plus diurne quand l'exploitation a cessé.

[Traduit par la Rédaction]

Received August 10, 1999. Accepted December 15, 1999.

A.M. Kitchen and E.R. Schauster. Department of Fisheries and Wildlife, Utah State University, Logan, UT 84322, U.S.A. E.M. Gese. ${ }^{1}$ National Wildlife Research Center, Department of Fisheries and Wildlife, Utah State University, Logan, UT 84322 , U.S.A.

${ }^{1}$ Author to whom all correspondence should be addressed (e-mail: egese@cc.usu.edu). 


\section{Introduction}

Patterns of activity develop in order to allow an animal to most efficiently exploit its environment while minimizing risk. Activity cycles are thus influenced by a number of environmental and individual factors. These factors include prey abundance and distribution (Daan 1981), seasonal changes (Mech 1970), avoidance of interspecific predation or human related activities (Kavanau 1971; Gese et al. 1989; Ciucci et al. 1997), the animal's physiological adaptations to activity during nocturnal and diurnal time periods (Kavanau and Ramos 1975; Daan 1981), and life-history strategies (e.g., hunting strategies and social organization) (Gittleman 1986).

Both the time and the intensity of activity can be temporally or geographically variable within species. For example, the documented activity patterns of wolves (Canis lupus) are highly variable between studies (e.g., Mech 1992; Vila et al. 1992). Wolves in Minnesota are exclusively nocturnal in summer but are active both diurnally and nocturnally in winter (Mech 1992). In contrast, wolves in Italy have been shown to be exclusively nocturnal (Ciucci et al. 1997). Such variation in activity patterns has often been attributed to differences in prey preferences and to prey abundance and distribution. The level of exploitation experienced by an animal may also influence activity patterns. Vila et al. (1992) noted an increase in nocturnal behavior in wolves in areas where human pressures were high, and suggested that this nocturnal behavior could be the result of wolves trying to reduce interactions with people.

Similarly, Kavanau and Ramos (1975) speculated that the mostly nocturnal activity of wild coyotes (Canis latrans) may be an adaptation to minimize contact with humans. Studies on coyote activity patterns have often found coyotes to be largely crepuscular and nocturnal (e.g., Andelt and Gipson 1979; Holzman et al. 1992). This predominance of nocturnal and crepuscular activity occurs despite evidence that coyote visual systems are best adapted to diurnal and crepuscular activity (Kavanau and Ramos 1975).

We compared coyote activity patterns estimated using radio-tracking locations between 1983 and 1988 with those documented between 1996 and 1997 on the Pinon Canyon Maneuver Site in southeastern Colorado, to test the hypothesis that changes in exposure to human persecution would result in changes in coyote activity patterns.

\section{Methods}

The study area was located on the $1040 \mathrm{~km}^{2}$ Pinon Canyon Maneuver Site (PCMS), Las Animas County, Colorado. The climate is semi-arid with a mean annual precipitation ranging between 26 and $38 \mathrm{~cm}$. Mean monthly temperatures range from $-1^{\circ} \mathrm{C}$ in January to $23^{\circ} \mathrm{C}$ in July. Elevations range from 1310 to $1740 \mathrm{~m}$. The site consists of river canyons, limestone breaks, and open plains. The two main vegetation types are shortgrass prairie and pinyon pine (Pinus edulis) - juniper (Juniperus monosperma) communities (Shaw et al. 1989). The study area was used primarily for cattle ranching prior to 1982 and, thus, predator populations (mostly coyotes and swift foxes (Vulpes velox)) had been subjected to trapping and shooting for $>50$ years. In 1982, the U.S. Army acquired PCMS for military activities that involve month-long mechanized training sessions 3-4 times a year on portions of the site. In 1987 and 1988, an estimated 50 and $63 \%$, respectively, of the coyotes on the study site were removed using helicopter gunning (E.M. Gese and O.J. Rongstad). ${ }^{2}$ Thus, coyotes tracked between 1983 and 1988 had experienced trapping and hunting by ranchers immediately prior to the monitoring period and intensive removal efforts during the final 2 years of the field study. In contrast, coyotes tracked during the 1996-1997 field study experienced some disturbance from army maneuvers that occurred in the area but had not been exposed to direct persecution (e.g., shooting) for 8 years.

Coyotes were radio-collared and tracked from 1983 to 1988 and again from 1996 to 1997 on PCMS. Coyotes were captured in the 1983-1988 field study using steel leg-hold traps, aerial darting (Baer et al. 1978), aerial net-gunning from a helicopter (Barrett et al. 1982; Gese et al. 1987), manual capture after aerial pursuit (Gese et al. 1987), or manual capture from all-terrain vehicles (Gese and Andersen 1993). Coyotes were captured in the 19961997 field study by aerial net-gunning from a helicopter (Barrett et al. 1982; Gese et al. 1987). Each coyote was ear-tagged, aged by tooth wear (Gier 1968), sexed, weighed, and radio-collared. Transmitter mass was $<5 \%$ of the body mass of the animal (Eberhardt et al. 1982). All radio collars included a mortality sensor that activated after $6 \mathrm{~h}$ of no motion. All coyotes were released at the site of capture.

Locations were obtained by triangulating 2-3 bearings of an animal's position in $<10 \mathrm{~min}$. Triangulation angles were maintained between $20^{\circ}$ and $160^{\circ}$ (Gese et al. 1988). Animal positions were determined using the software package Locate (Pacer, Truro, Nova Scotia). Telemetry error was determined with reference transmitters to be $\pm 8^{\circ}$. Aerial telemetry (Mech 1983) was employed to locate missing animals. Sequential tracking was used to assess the activity patterns of coyotes. Locations were taken every $0.5 \mathrm{~h}$, and the distances between locations calculated. We used the mean distance traveled/hour $(\mathrm{km} / \mathrm{h})$ in statistical comparisons. Distances traveled during the dawn (05:00-09:00), day (09:00-17:00), evening (17:00$21: 00)$, night (21:00-05:00), and overall (24 h) were compared between study periods (1983-1988 versus 1996-1997) using Student's $t$ tests.

Estimates of prey use by the coyotes in both field studies were obtained to test an alternate hypothesis that prey switching may explain the changes in coyote movements. Dietary overlap between coyotes in the two field studies was examined using scat analysis. Scats were collected monthly along transects and associated roads. Scats were oven-dried for $\geq 24 \mathrm{~h}$ before analysis. Skeletal and hair reference collections and hair keys (Moore et al. 1974) were used to identify food items. The frequency of occurrence of different food items in each scat was recorded. The frequency of occurrence of prey items was calculated by recording the presence or absence of the item in a scat. Only prey items comprising $>20 \%$ of volume were included, to minimize the likelihood of overestimation of small prey (Martin et al. 1946; Weaver and Hoffman 1979). Mammal species were divided into those that were active diurnally and those that were active nocturnally. Overall and seasonal differences in diet between the two field studies were calculated using $\chi^{2}$ analysis with Statistical Analysis Systems (SAS Institute Inc. 1988). For the purposes of analyses, we defined seasons on the basis of energetic demands (due to climatic changes and prey abundance) and behavioral characteristics (including breeding, gestation, puprearing, and dispersal) as follows: pup-rearing season (15 April 14 August), dispersal season (15 August - 14 December), and breeding-gestation season (15 December - 14 April).

\footnotetext{
${ }^{2}$ E.M. Gese and O.J. Rongstad. 1989. Final report: the ecology of coyotes on the Pinon Canyon Maneuver Site, Colorado 1983-1988. Unpublished report. U.S. Army, Directorate of Environmental Compliance and Management (DECAM), Fort Carson, Colorado.
} 
Fig. 1. Movement rates $(\mathrm{km} / \mathrm{h})$ of coyotes over a $24-\mathrm{h}$ period on the Pinon Canyon Maneuver Site, Colorado, during the 1983-1988 and 1996-1997 field studies. Bars represent standard errors.

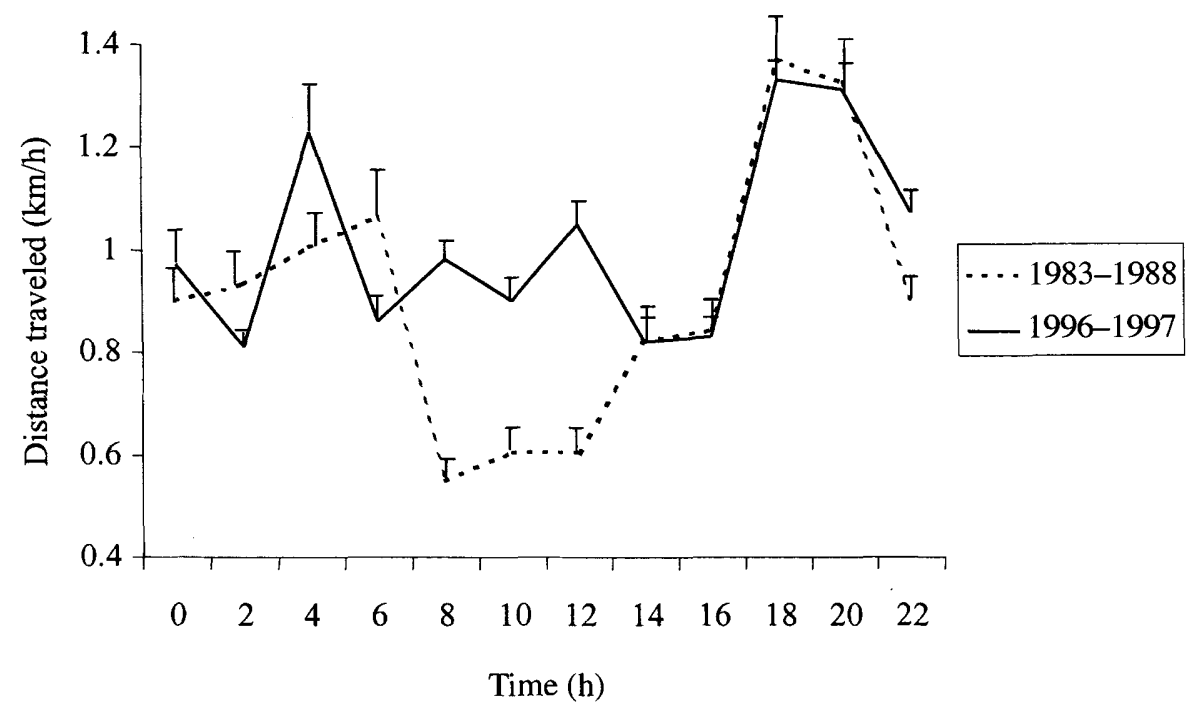

Table 1. Mean movement rates $(\mathrm{km} / \mathrm{h})$ of coyotes during the 1983-1988 and 1996-1997 field studies during the periods of dawn, day, evening, and night, and overall ( $24 \mathrm{~h}$ ), on Pinon Canyon Maneuver Site, Colorado, and the results of Student's $t$ tests comparing these rates.

\begin{tabular}{llllllll}
\hline & \multicolumn{3}{l}{$\begin{array}{l}\text { Mean movement rate } \\
(\mathrm{km} / \mathrm{h})\end{array}$} & & & & \\
\cline { 2 - 3 } \cline { 5 - 7 } & $1983-1988$ & $1996-1997$ & & $t$ & $\mathrm{df}$ & $P$ \\
\hline Dawn & 1.01 & 0.99 & 0.10 & 34 & 0.92 \\
Day & 0.68 & 0.97 & & 2.94 & 67 & 0.004 \\
Evening & 1.12 & 0.86 & & 1.46 & 59 & 0.15 \\
Night & 0.98 & 1.00 & & 0.27 & 58 & 0.79 \\
Overall $(24 \mathrm{~h})$ & 0.85 & 0.94 & & 1.15 & 67 & 0.253 \\
\hline
\end{tabular}

\section{Results}

From August 1983 to July 1988, 49 coyotes (26 males and 23 females) were tracked for $>2400 \mathrm{~h}$ using radiotelemetry. From April 1996 to August 1997, 22 coyotes (12 males and 10 females) were tracked for $>950 \mathrm{~h}$. The average rate of diurnal movement of the coyotes in the 1996-1997 field study was significantly higher than that of the coyotes in the 19831988 field study (Fig. 1; Table 1). This occurred despite no significant increase in the overall $(24 \mathrm{~h})$ rate of movement of the coyotes between the two field studies (Table 1). Movement rates in crepuscular hours were slightly, although not significantly, higher in the 1983-1988 field study than in the 1996-1997 field study, and movement rates in nocturnal hours were not significantly different between the two studies.

Diurnally active mammalian prey items identified in coyote scats included ground squirrels (Spermophilus spp.), blacktailed prairie dogs (Cynomys ludovicianus), and pronghorn (Antilocapra americana), and nocturnally active mammalian prey species included cottontail rabbits (Sylvilagus audubonii), black-tailed jackrabbits (Lepus californicus), pocket gophers (Pappogeomys spp.), pocket mice (Perognathus spp.), kangaroo
Table 2. The seasonal and overall frequencies of occurrence (\%) of diurnally and nocturnally active mammalian prey species in the diets of coyotes in the 1983-1988 and 1996-1997 field studies, on Pinon Canyon Maneuver Site, Colorado, and $\chi^{2}$ values showing comparisons between the two studies.

\begin{tabular}{llclll}
\hline Season & $\begin{array}{l}\text { Field } \\
\text { study }\end{array}$ & $\begin{array}{l}\text { Diurnal } \\
\text { mammals }\end{array}$ & $\begin{array}{l}\text { Nocturnal } \\
\text { mammals }\end{array}$ & $\chi^{2}$ & $P$ \\
\hline Pup rearing & $1983-1988$ & 9.45 & 81.07 & 1.61 & 0.20 \\
& $1997-1998$ & 11.47 & 54.13 & & \\
Dispersal & $1983-1988$ & 1.05 & 35.00 & 2.69 & 0.10 \\
& $1997-1998$ & 7.10 & 48.20 & & \\
Breeding- & $1983-1988$ & 4.03 & 56.72 & 0.34 & 0.56 \\
gestation & & & & & \\
Overall & $1997-1998$ & 3.60 & 66.19 & & \\
& $1983-1988$ & 4.84 & 57.60 & 0.79 & 0.37 \\
& $1997-1998$ & 7.39 & 56.17 & & \\
\hline
\end{tabular}

rats (Dipodomys spp.), harvest mice (Reithrodontomys spp.), deer mice (Peromyscus spp.), grasshopper mice (Onychomys spp.), woodrats (Neotoma spp.), and mule deer (Odocoileus hemionus). There was no significant difference between the frequency of occurrence of diurnally versus nocturnally active mammalian prey species in the diets of coyotes in any season or overall between the 1983-1988 and 1996-1997 field studies (Table 2).

\section{Discussion}

Human exploitation can influence individual animals in a number of ways and can have damaging effects on populations (e.g., Hume 1976). A common response to exploitation is avoidance, which may result in a shifted activity pattern, leaving the animal unable to utilize a spatial or temporal resource to its full potential. Changes in activity patterns due to human exploitation have been documented previously in a variety of animals. For example, mountain lions (Felis concolor) 
adjusted their movement peaks in response to logging activity in Utah and Arizona (Van Dyke et al. 1986). Burger and Gochfeld (1991) documented that sanderlings (Calidris alba) would decrease the amount of human exploitation they encountered by feeding at night.

This study demonstrated that coyote activity patterns can be influenced by the exploitation, in this case by humans, experienced by the animal. Since human activity often occurs during diurnal hours, coyotes on the PCMS during the 1983-1988 field study responded to human exploitation by restricting their diurnal movements. Historically, the exploitation experienced by these coyotes was direct, mostly shooting-a form of persecution to which they could not become habituated and, thus, avoided. After a period of 8 years during which the coyote population experienced almost no direct human persecution, diurnal movement increased significantly. The disturbance experienced by the coyotes during the 1996-1997 field study involved the execution of army maneuvers on portions of the site, not direct persecution. Such indirect disturbance permits habituation and is unlikely to necessitate avoidance. The shift to diurnal activity in the unexploited population was to be expected in the light of evidence that the visual systems of coyotes are best adapted to diurnal and crepuscular hours (Kavanau and Ramos 1975) and that, therefore, coyotes are likely to be more effective in obtaining prey during these periods. It has been suggested previously (Kavanau and Ramos 1975; Vila et al. 1992) that the prevalence of nocturnal activity documented in some wild canids (e.g., wolves and coyotes) is a direct result of exposure to human exploitation. Indeed, high levels of diurnal activity have been recorded in an unexploited coyote population (e.g., Gese et al. 1996).

Activity pattern changes in animals will also be affected by their ability to maintain established space-use patterns when under exploitation pressure. Changes in space use have been documented for a number of animals in areas in which human exploitation occurs. For example, Gill et al. (1996) found that the extent to which feeding grounds were utilized by pink-footed geese (Anser brachyrhynchus) declined linearly with increasing risk from surrounding roads. Mountain lions in Arizona and Utah established home ranges with road densities lower than the study site average (Van Dyke et al. 1986). Individual variation in spatial response to exploitation has also been documented. Gese et al. (1989) found that the spatial response of coyotes to human disturbance was influenced by the duration of the disturbance, topography, and the amount of available cover in the area of a coyote's home range.

Coyotes on PCMS altered their activity patterns in response to changes in exploitation. The coyote population that was exploited by humans for $>50$ years was principally crepuscular and nocturnal. No more than 8 years after persecution ceased, the coyotes were found to have adopted a more diurnal activity pattern. Individual response to human or other exploitation is likely to vary among coyote populations, and to depend on a coyote's ability to habituate to, or shelter from, the exploitation. This will be influenced by the attributes of an animal's range, including the amount of cover and topography in the range, and with the intensity and the manner of the exploitation.

\section{Acknowledgements}

Many thanks go to Becky Abel, Cass Bromley, Julian Colescott, Chris Gordon, Linda Gorman, Chad Hamlin, Racheal Hare, Seija Karki, Mead Klavetter, Steve Langeland, Scott McLellan, Melissa Pangraze, Laurence Schafer, Laurie Schleub, Jen Stamp, Hilary Tall, Pat Terletzky, and Whitney Weber for field assistance. Dan Sharps, Bruce Roselund, Gary Belew, Chris Bandy, and Tom Warren provided technical and logistical support. Funding and logistical support were provided by the U.S. Army, Directorate of Environmental Compliance and Management (DECAM), Fort Carson, Colorado; the U.S. Fish and Wildlife Service, Colorado Fish and Wildlife Assistance Office, Golden, Colorado; the Northern Prairie Science Center, Jamestown, North Dakota; the USDA National Wildlife Research Center, Logan, Utah; the Utah Cooperative Fish and Wildlife Research Unit; and Utah State University Presidential and Berryman Fellowships to the senior author. Research protocols were approved by Institutional Animal Care and Use Committees (IACUC) at the National Wildlife Research Center and Utah State University.

\section{References}

Andelt, W.F., and Gipson, P.S. 1979. Home range, activity and daily movements of coyotes. J. Wildl. Manage. 43: 944-951.

Baer, C.H., Severson, R.E., and Linhart, S.B. 1978. Live capture of coyotes from a helicopter with ketamine hydrochloride. J. Wildl. Manage. 42: 452-454.

Barrett, M.W., Nolan, J.W., and Roy, L.D. 1982. Evaluation of a hand-held net-gun to capture large animals. Wildl. Soc. Bull. 10: 108-114.

Burger, J., and Gochfeld, M. 1991. Human activity influence and diurnal and nocturnal foraging of sanderlings (Calidris alba). Condor, 93: 259-265.

Ciucci, P., Boitani, L., Francisci, F., and Andreoli, G. 1997. Home range, activity and movements of a wolf pack in central Italy. J. Zool. (Lond.), 243: 803-819.

Daan, S. 1981. Adaptive daily strategies in behavior. Handbook Behav. Neurobiol. 4: 275-298.

Eberhardt, L.E., Hanson, W.C., Bengtson, J.L., Garrot, R.A., and Hanson, E.E. 1982. Arctic fox home-range characteristics in an oil-development area. J. Wildl. Manage. 46: 183-190.

Gese, E.M., and Andersen, D.E. 1993. Success and cost of capturing coyotes, Canis latrans, from all-terrain vehicles. Can. FieldNat. 107: 112-114.

Gese, E.M., Rongstad, O.J., and Mytton, W.R. 1987. Manual and net-gun capture of coyotes from helicopters. Wildl. Soc. Bull. 15: 444-445.

Gese, E.M., Rongstad, O.J., and Mytton, W.R. 1988. Home-range and habitat use of coyotes in southeastern colorado. J. Wildl. Manage. 52: 640-646.

Gese, E.M., Rongstad, O.J., and Mytton, W.R. 1989. Changes in coyote movements due to military activity. J. Wildl. Manage. 53: 334-339.

Gese, E.M., Ruff, R.L., and Crabtree, R.L. 1996. Foraging ecology of coyotes (Canis latrans): the influence of extrinsic factors and a dominance hierarchy. Can. J. Zool. 74: 769-783.

Gier, H.T. 1968. Coyotes in Kansas. Kans. Agric. Exp. Stn. Bull. No. 393. 
Gill, J.A., Sutherland, W.J., and Watkinson, A.R. 1996. A method to quantify the effects of human disturbance on animal populations. J. Appl. Ecol. 33: 786-792.

Gittleman, J.L. 1986. Carnivore life history patterns: allometric, phylogenetic, and ecological associations. Am. Nat. 127: 744771.

Holzman, S., Conroy, M.J., and Pickering, J. 1992. Home range, movements, and habitat use of coyotes in southcentral Georgia. J. Wildl. Manage. 56: 139-146.

Hume, R.A. 1976. Reactions of goldeneyes to boating. Br. Birds, 69: $178-179$.

Kavanau, J.L. 1971. Locomotion and activity phasing of some medium-sized mammals. J. Mammal. 52: 386-403.

Kavanau, J.L., and Ramos, J. 1975. Influences of light on activity and phasing of carnivores. Am. Nat. 109: 391-418.

Martin, A.C., Gensch, R.H., and Brown, C.P. 1946. Alternative methods in upland gamebird food analysis. J. Wildl. Manage. 10: $8-12$.

Mech, L.D. 1970. The wolf: the ecology and behavior of an endangered species. Doubleday/Natural History Press, Garden City, N.Y.

Mech, L.D. 1983. Handbook of animal radiotracking. University of Minnesota Press, Minneapolis.
Mech, L.D. 1992. Daytime activity of wolves during winter in northeastern Minnesota. J. Mammal. 73: 570-571.

Moore, T.D., Spencer, L.E., and Dugnolle, C.E. 1974. Identification of the dorsal guard hairs of some mammals of Wyoming. Wyo. Game Fish Comm. Bull. No. 14.

SAS Institute Inc. 1988. SAS/STAT user's guide, version 6.12 edition. SAS Institute Inc., Cary, N.C.

Shaw, R.B., Anderson, S.L., Schulz, K.A., and Diersing, V.E. 1989. Plant communities, ecological checklist, and species list for the U.S. Army Pinon Canyon Maneuver Site, Colorado. Colo. State Univ. Sci. Ser. No. 37.

Van Dyke, F.G., Brocke, R.H., Shaw, H.G., Ackerman, B.B., Hemke, T.P., and Lindzey, F.G. 1986. Reactions of mountain lions to logging and human activity. J. Wildl. Manage. 50: 95-102.

Vila, C., Urios, V., and Castroviejo, J. 1992. Observations on the daily activity patterns in the Iberian wolf. In Ecology and conservation of wolves in a changing world. Edited by L.N. Carbyn, S.H. Fritts, and D.R. Seip. Canadian Circumpolar Institute, University of Alberta, Edmonton. pp. 335-340.

Weaver, J.L., and Hoffman, S.W. 1979. Differential detectability of rodents in coyote scats. J. Wildl. Manage. 43: 783-786. 